\title{
RITUAL NYELUNG DI DESA ADAT BUAHAN DAN BUAHAN KAJA, PAYANGAN, GIANYAR, BALI (LATAR BELAKANG DAN POTENSINYA SEBAGAI SUMBER BELAJAR SEJARAH DI SMA)
}

\author{
I Wayan Edi Setiawan \\ e-mail : iwayanedisetiawan@gmail.com
}

\begin{abstract}
ABSTRAK
Penelitian ini bertujuan (1) Mendeskripsikan latar belakang Desa Buahan dan Buahan Kaja melakukan ritual Nyelung, (2) Mendeskripsikan prosesi pelaksanaan ritual Nyelung, (3) Mengetahui Aspek-aspek dari ritual Nyelung yang dapat digunakan sebagai sumber belajar sejarah di SMA. Penelitian ini menggunakan metode kualitatif dengan tahap-tahap; (1) Memilih lokasi penelitan berada di Desa Adat Buahan dan Buahan Kaja, (2) Teknik penentuan informan dilakukan dengan menggunakan teknik Purposive Sampling dan juga Snow Ball, (3) Teknik penjaminan keaslian data menggunakan Triangulasi Data dan Triangulasi Metode, (4) Teknik pengumpulan data dilakukan dengan Observasi, Wawancara, Studi Dokumentasi dan Teknik Analisis Data. Hasil penelitian menunjukan bahwa, (1) Latar belakang sejarah ritual Nyelung di Desa Adat Buahan dan Buahan merupakan upacara yang dilakukan sebagai wujud rasa syukur atas hasil-hasil pertanian. (2) Tahapan pelaksanaan ritual Nyelung adalah dimulai dari tahapan persiapan ritual, tahap pelaksanaan ritual yang meliputi (a) Negen Jelung, (b) Mekideh, (c) Mekeleb. Dan tahapan terakhir yakni penutupan ritual. (3) Aspek-aspek dari ritual Nyelung yang dapat digunakan sebagai sumber belajar Sejarah di SMA adalah sebagai berikut: Aspek sejarah dan Aspek pendidikan karakter yang diimplementasikan dalam bentuk buku suplemen.
\end{abstract}

Kata Kunci : Sejarah, Ritual Nyelung, Sumber Belajar Sejarah.

\begin{abstract}
This study aims to (1) describe the background of the village of Buahan and Buahan Kaja performing the Nyelung ritual, (2) Describe the procession of the Nyelung ritual, (3) Know the aspects of the Nyelung ritual that can be used as a source of historical learning inHigh School. This study uses qualitative methods with stages; (1) Selecting the location of the research in the DesaAdat Buahan and Buahan Kaja, (2) The technique of determining the informant is done by using Purposive Sampling and Snow Ball techniques, (3) Techniques for guaranteeing the authenticity of the data using Triangulation Data and Triangulation Method, Data collection is done by Observation, Interview, Documentation Study and Data Analysis Technique. The results of the study show that, (1) the historical background of the Nyelung ritual in the Desa Adat Buahan and Buahan is a ceremony carried out as a form of gratitude for agricultural products. (2) The stages of implementing the Nyelung ritual are starting from the stage of ritual preparation, the stage of ritual implementation which includes (a) Negen Jelung, (b) Mekideh, (c) Mekeleb. And the last stage is the closing of the ritual. (3) Aspects of the Nyelung ritual which can be used as learning resources History in high school are as follows: Historical aspects and aspects of character education are implemented in the form of supplementary books.
\end{abstract}

Keywords: History, Nyelung Ritual, Historical Learning Resources. 


\section{PENDAHULUAN}

Bali merupakan daerah yang tidak dapat dilepaskan dari suatu keyakinan dan kepercayaan serta tradisi-tradisi yang dianggap suatu mitos bagi masyarakatnya. Wiana (2004) menjelaskan kata Bali berasal dari bahasa Sansekerta yang berarti kekuatan maha agung. Andakusuma(1986) menunjukkan kata Bali tidak saja berarti kuat, tetapi bisa pula berarti mulia (Atmadja, 2016: 15).

Meskipun tradisi sampai dengan ritual yang ada di masing-masing desa berbeda, namun pada intinya maksud dan tujuan dari ritual tersebut hampir seluruhnya sama yaitu sebagai ungkapan raya syukur kepada Tuhan atas segala karunia yang diberikan. Perbedaan tersebut terjadi karena disebabkan adanya konsepdesa, kala, patra, tetapi tetapdibingkai oleh nilai keseimbangan hukum alam yang mengacu pada inti filsafat Tri Hita Karana. (Wiana, 2002: 113-114).

Berdasarkan konsep di atas maka dapat diartikan bahwa bentuk ritual yang ada dalam masyarakat Bali bersumber dari konsep Tri Hita Karana yang mengacu pada konteks hubungan manusia dengan alam lingkungan. Salah satu desa di Kabupaten Gianyar yang masih melestarikan ritual adalah Desa Buahan dan Buahan Kaja, Payangan Gianyar.

Menurut Jero Mangku Wayan Mahardika (50 tahun) selaku pemangku yang terlibat dalam ritual menyatakan bahwa :

"Nyelung secara harfiah berasal dari kata Nyak Luwung (mau bagus, baik, positif). Jadi tolak ukurnya adalah warga diberikan kebaikan dan kemakmuran dari segi sandang, pangan dan papan" (wawancara, 21 Desember 2018).
Bertahannya suatu ritual tersebut sampai dengan saat ini mengindikasikan bahwa ritual memiliki fungsi yang sangat penting dalam kehidupan masyarakat umum dan khususnya masyarakat Desa Buahan dan Buahan Kaja sehingga perlu dipertahankan keberadaannya.

Jika dilihat pada kurikulum 2013 mata pelajaran sejarah kelas X di SMA pada Kompetensi Inti (KI) bisa dilihat pada KI 3 yaitu memahami, menerapkan, dan menganalisis pengetahuan factual, konseptual dan prosedural berdasarkan rasa ingin tahunya tentang ilmu pengetahuan, teknologi, seni, budaya dan humaniora dengan wawasan kemanusiaan kebangsaan kenegaraan dan peradaban terkait fenomena dan kejadian serta menerapkan pengetahuan prosedural pada bidang kajian yang spesifik sesuai dengan bakat dan minatnya untuk memecahkan masalah.

Sementara itu, untuk kompetensi dasarnya (KD): menganalisis keterkaitan kehidupan awal manusia Indonesia dibidang kepercayaan, budaya, ekonomi dan teknologi serta pengaruhnya dalam kehidupan masa kini.Kajian teori yang digunakan dalam penelitian ini menyangkut tentang (1) Latar belakang pelaksanaan ritual (2) Prosesi sebuah ritual (3) Ritual sebagai media pendidikan karakter (4) Buku suplemen sebagai sumber belajar.

\section{METODE PENELITIAN}

Motode penelitian yang digunakan dalam penelitian ini adalah metode deskriptif kualitatif . Langkah-langkah penelitian ini meliputi: (1) Teknik penentuan lokasi penelitian, (2) Teknik penentuan informan, dalam penelitian ini penulis menggunakan teknik purposive sampling. Kemudian dikembangkan lagi 
dengan teknik "Snow Boll" (3) Teknik pengumpulan data, adapun metode yang dilakukan antara lain: teknik observasi, wawancara, teknik dokumentasi, (4) Teknik penjaminan keaslian data antara lain: triangulasi data dan triangulasi metode, (5) Teknik analisis data (6) Teknik penyusunan buku suplemen.

\section{PEMBAHASAN}

\subsection{Latar Belakang Historis Pelaksanaan Ritual Nyelung}

Ritual Nyelungsangat disakralkan oleh masyarakat Desa Buahan dan Buahan Kaja, adapun asal-usul sejarah ritual Nyelung, menurut informan Jero Mangku Wayan Mahardika (55 tahun), selaku salah satu pemangku yang terlibat dalam pelaksanaan ritual Nyelung mengungkapkan bahwa asal-usul dari upacara Nyelung disebabkan karena pada jaman dahulu Desa Buahan mengalami paceklik yang berkepanjangan, paceklik pertanian padi masyarakat tersebut disebabkan adanya serangan hama seperti : tikus, welang sangit dan penyakit pertanian lainnya.

Melihat keadaan yang sedemikian sulit terkait dengan hasil pertanian masyarakat. Akhirnya krama subak atas saran dari pengelingsir Desa Buahan (nenek moyang) memohon petunjuk kepada Ida Sang Hyang Widhi Wasa di Pura Pucak Pausan, yang terletak di banjar Pausan. Lokasi dari Pura tersebut berada pada posisi atau tempat paling tinggi di Desa Buahan Kaja dan disekitar areal Pura juga terdapat sumber mata air yang sangat besar dan banyak, sumber mata air ini digunakan atau dimanfaatkan oleh masyarakat untuk mengairi tanah persawahan mereka

Sesampainya di tempat tersebut, masyarakat memohon ke hadapan Tuhan
Yang Maha Esa. Dengan demikian warga berjanji akan mengharturkan hasil-hasil pertanian masyarakat. Tirta atau air suci yang diambil di Pura Pucak Pausan untuk selanjutnya akan dipercikan ke lahan persawahan yang digarap oleh krama subak, dalam kurun waktu musim panen selanjutnya alhasil penyakit yang dahulu menyerang pertanian warga berangsurangsur menghilang. Dengan demikian sesuai dengan sesangi (perjanjian) maka krama subak menghaturkan hasil-hasil pertanian baik berupa buah-buahan/ umbiumbian (pala gantung dan pala bungkah) kepada Ida Sang Hyang Widhi Wasa.

\subsection{Kekhawatiran Akan Hal-hal Gaib.}

Lahirnya ritual Nyelung tidak bisa dilepaskan dari karakteristik masyarakat Desa Buahan dan Buahan Kaja yang dulu hampir sebagaian besar penduduknya bermatapencaharian sebagai petani. Apabila permasalahan yang dihadapi oleh petani tidak dapat diselesaikan dengan teknologi, maka dari itu masyarakat sangat mengharapkan bantuan alam khususnya alam Niskala, melalui pelaksanaan ritual, salah satunya melaksanakan ritual Nyelung yang tujuannya tidak lain ialah untuk memohon kesuburan dalam arti luas. Oleh karena itu, masyarakat juga memaknai sebagai akibat pengaruh alam gaib (Niskala) yang mengganggu, sehingga untuk mengatasinya dilakukan suatu rupacara yakni lewat ritual Nyelung.

\subsection{Media Memohon Kesuburan}

Masyarakat Desa Buahan dan Buahan Kaja memiliki keyakinan akan kekuasaan Ida Sang Hyang Widhi Wasa dengan segala berkah dan anugrahnya, hal ini menjadi salah satu faktor pendorong lahirnya ritual Nyelung di Desa Buahan dan Buahan Kaja. Pelaksanaan ritual 
Nyelung juga dimaknai sebagai upaya untuk memohon kesuburan kepada Ida Sang Hyang Widhi Wasa, dalam manifestasinya sebagai Dewi Sriyang merupakan lambang Dewi kesuburan.Adanya fungsi sakral ini, membuat masyarakat Desa Buahan dan Buahan Kaja, takut jika tidak melaksanakan ritual Nyelung dan berusaha tetap mendekatkan diri kepada Ida Sang Hyang Widhi Wasa.

\subsection{MemperkuatTri Hita Karana}

\section{a. Parahyangan}

Umat Hindu di Bali khususnya percaya akan filsafat Hindu Tri Hita Karana yaitu salah satunya menjaga hubungan baik dengan Tuhan. Begitu juga dengan ritual Nyelung yang sangat berhubungan dengan filsafat Hindu Tri Hita Karana tersebut. Seperti halnya untuk menjaga hubungan harmonis terhadap Tuhan Yang Maha Esa. Dimana pada saat ritual Nyelung, masyarakat Desa Buahan dan Buahan Kaja melaksanakan persembahyangan di Pura Pucak Pausan dan Pura Subak dimasing-masing kewilayahan banjar.

\section{b. Pawongan}

Pelaksanaan ritual Nyelung dapat dikatakan memiliki fungsi memperkuat hubungan sosial/ antar sesama masyarakat, sebab dikarenakan pelaksanaan ritual dapat menumbuhkan hubungan harmonis dengan masyarakat satu dengan yang lainnya. Bentuk integritas sosial dalam ritual adalah adanya rasa saling memiliki seperti upacara yang telah melekat pada seluruh bagian dari anggota untuk bersmasama dan saling bergotong royong dalam melaksanakan ritualnya.

Dengan dilaksanakannya ritual Nyelung, menjadi satu solusi bagi warga untuk berinteraksi serta berkomunikasi dengan warga lainnya. Dengan saling berkomunikasi secara otomatis warga akan saling mengenal antara satu dengan yang lainnya. Dengan adanya ritual Nyelung dapat menumbuhkan kebersamaan dan dapat menciptakan adanya solidaritas sosial untuk masyarakat Desa Buahan dan Buahan Kaja.

\section{c. Palemahan}

Masyarakat Bali selalu berusaha menjaga keseimbangan dalam hidupnya dengan berlandaskan filsafat Tri Hita Karana, yang mengandung pengertian tiga penyebab kesejahteraan atau kebahagiaan (Ngurah, dkk, 1999: 99) dan mengaplikasikannya dalam kehidupan sehari-hari.

Tujuannya ritual Nyelunguntuk mengucapkan rasa syukur serta memohonon keselamatan terhadap pertanian warga. Rasa syukur diucapkan kepada Tuhan Yang Maha Esa, dalam manifestasinya sebagai Dewi Sri atas hasil panen yang telah dilimpahkan, ini sangat berkaitan dengan konsep Tri Hita Karana, yaitu hubungan harmonis antara manusia dengan lingkungan.

\subsection{Pemertahanan Kesenian dan Tradisi Banten}

Dalam setiap pelaksanaan ritual Nyelung didalamnya terdapat unsur-unsur kesenian. Diantaranya seni musik, ini dapat diamati dalam pelaksanaan ritual yang senantiasa diiringi dengan gambelan baleganjur, baleganjur dimainkan oleh anggota masyarakat yang tergabung dalam sekha gong. Disamping itu, terdapat pula seni tari. Seni tari akan dilaksanakan pada saat puncak dari pelaksanaan ritual Nyelung, adapun tarian yang dipentaskan antara lain seperti :tari baris, tari rejang dewa dan tari topeng sidakarya. Adapun penari yang terlibat, ialah truna-truni yang 
telah ditunjuk sebagai perwakilan dari masing-masing Banjar.

Selain untuk pemertahanan kesenian yang tidak kalah penting ialah pemertahanan tradisi bebantenan. Mengingat pada era sekarang, banyak generasi muda tidak paham dalam membuat banten. Dalam proses pembuatannya melibatkan seluruh banjar, dengan adanya pembagian pembuatan banten pada masing-masing banjar. Ini merupakan salah satu cara untuk melibatkan generasi muda di masingmasing banjar.

Dalam ritual ini juga terdapat nilai estetis. Hal ini dapat kita lihat dari penjor yang digunakan dalam ritual Nyelung. Penjor adalah sebuah tiang bambu tinggi yang dihiasai dengan janur, hasil-hasil bumi dan kain warna kuning-putih.

Bahan dasar penjor adalah tiang bambu sebagai simbol gunung. Kemudian berisi berbagai hasil bumi seperti buah kelapa, padi, dan lainnya. Juga terdapat daun andong, daun beringin dan daun plawa. Ada juga lamak, sampyan, dan jenis jejahitan lainnya. Diujung penjor berisikan kain putih sebagai lambang kesucian.

\subsection{Ritual Nyelung sebagai Destinasi Pariwisata \\ Menurut informan Wayan}

Sudarmika (35 tahun) yang merupakan salah satu pelaku wisata (gaid) lokal asli banjar Selat. Terkait dengan ritual Nyelung sebagai destinasi pariwisata khsususnya di desa Buahan. Beliau menyatakan bahwa :

"Ritual Nyelung merupakan tradisi unik yang terdapat di Desa Buahan dan Buahan Kaja terkait dengan waktu pelaksanaanya 10 tahun sekali.
Keunikan ritual ini bisa dimanfaatkan sebagai destinasi pariwisata wilayah Desa Buahan. Banyak wisatawan dalam negeri maupun luar negeri yang menantikan pelaksanaan Nyelung karena dirasa memiliki ciri khas yang tidak dimiliki tradisi lainnya. Wisatawan sebagian besar jenuh dengan hal-hal yang sering mereka tonton. Ritual Nyelung sebagai destinasi pariwisata memiliki peluang yang sangat besar dalam menarik hati wisatawan, terlebih lagi di desa Buahan dan Buahan kaja telah berdiri hotel dan villa bertarap nasional antara lain : Hotel Hanging Garden, Hotel Nandini, Villa Awan Biru, Villa Dara Ayu dan Villa The Stones Ubud" (wawancara, 7 April 2019)

Merujuk pada paparan di atas. Hal ini dapat dijadikan sebagai salah satu objek wisata bagi para wisatawan yang berkunjung ke Bali khsuusnya di Desa Buahan dan Buahan Kaja.

\subsection{Prosesi Pelaksanaan Ritual Nyelung di Desa Adat Buahan dan Buahan Kaja}

Ritual Nyelung sudah dilaksanakan secara turun-temurun serta diwariskan oleh nenek moyang/ leluhur masyarakat Desa Buahan dan Buahan Kaja. Adapun tahapan dalam pelaksanaan ritual Nyelung adalah sebagai berikut :

\section{a. Tahap Mempersiapkan Ritual Nyelung \\ Persiapan-persiapan yang} dilakukan oleh masyarakat Desa Buahan dan Buahan Kaja yang pertama adalah melakukan rapat-rapat yang dihadiri oleh perbekel dari kedua desa, kelihan se-desa Buahan dan Buahan Kaja, kelihansubak, sekretaris desa, bendahara desa, para pemangku dan tukang banten.Dan hasil 
paruman akan disesialisasikan ke krama dimasing-masing banjar.

Ritual Nyelung dilaksanakan di Pura Pucak Pausan sesuai dengan latar belakang munculnya ritual Nyelung, Dimana Pura ini sebagai tempat untuk memohon petunjuk (sesangi) dalam mengatasi paceklik yang terjadi pada lahan pertanian masyarakat. Selain itu tempat dari pura ini berada ditempat yang paling tinggi di DesaBuahan dan Buahan Kaja dan memiliki banyak sumber mata air baik yang digunakan sebagai air minum maupun digunakan sebagai air irigasi yang mengairi tanah persawahan masyarakat Desa Buahan dan Buahan Kaja.

$$
\text { Pelaksanaan ritual Nyelung }
$$
memerlukan beberapa sarana banten dalam pelaksanaanya. banten tersebut mempunyai makna dan simbol-simbol tertentu, yang ditunjukkan kehadapan Ida Sang Hyang Widhi Wasa. Secara umum Banten yang diperlukan dalam pelaksanaan ritual Nyelung, ialah sebagai berikut (1) BantenSuci, (2) BantenPejati, (3) BantenBebangkit.

Pelaksanaan ritual Nyelung yang memakai banten, ditunjukkan kepada Ida Sang Hyang Widhi Wasa dalam manifestasinya sebagai Dewi Sri. Yang merupakan lambang Dewi kesuburan atau kemakmuran. Disamping hal-hal yang telah dijelaskan di atas terpada pula beberapa Uparengga yang diperlukan, sebagai pelengkap ritual antara lain (1) Sanggah Cucuk, (2) Penjor, (3) Klakat, (4) Klabang, (5) Sengkui, (6) Umbul-umbul, (7) Tedung.

\section{b. Tahap Pelaksanaan Ritual Nyelung.}

Pada tahap pelaksanaan ritual akan dimulai dengan Negen (membawa)Jelung yang merupakan proses pertama, arak- arakan Jelung akan dimulai dari Pura Pusehbanjar Buahan, Desa Buahan karena ditempat inilah peralatan ritual dibuat.

Upacara ini tidak berhenti hanya pada membawa Jelung sampai di Pura Pucak Pausan, melainkan akan dilanjutkan dengan upacara Mekideh atau Jelung memutari areal Pura Pucak Pausan sebanyak 3 kali putaran berlawanan arah dengan jarum jam. Upacara Mekideh mempunyai maksud dan tujuan yang sangat bermakna dalam kehidupan masyarakat.

Upacara mekideh juga diiringi dengan gambelan baleganjur dan krama subakakan bergantian membawa Jelung untuk mengelilingi areal Pura. Setelah acara mekideh selesai dilakukan, akan dilanjutkan dengan membawa Jelung ke areal utama Pura (Jeruan) setelah Jelung sampai di Jeruan akan dilanjutkan dengan upacara Mekeleb.

Mekeleb mempunyai makna mengahaturkan hasil-hasil pertanian (sesaji) tersebut secara tulus iklas dan tidak dibawa pulang lagi. Tujuan ritual ini ialah Moksartham Jagadhita ya ca iti Dharma untuk mencapai kebahagiaan rohani dan kesejahteraan hidup jasmani atau kebahagiaan lahir dan batin.

\section{c. Penutupan Ritual Nyelung}

Pada tahap penutupan acara, tidak saja dengan dilakukan persembahyangan. Dimana dengan bersamaannya pelaksanaan antara ritual Nyelung dengan karya agung di Pura Pucak Pausan yang yang sepenuhnya disungsung oleh kramabanjar Pausan. Selanjutnya Jero mangkuakan menghaturkan segehan warna lima di depan petapakan Ida Bhatara (barong dan rangda) dan juga di depan para pengiring yang kerasukan guna sebagai persembahan untuk bhuta kala 
agar tidak menggangu pengiring maupun Bhatara Petapakan. Setelah itu para pelawatan yang berupa Barong dan Rangda serta petapakan yang lainnya akan dibawa kembali ke puranya masingmasing. Pada proses ini sepenuhnya dilaksanakan oleh krama banjar Pausan. Sedangkan kramabanjar di luar banjar Pausan setelah penyinebanpetapakan Ida Bhatara dilaksanakan, akan dilanjutkan dengan pelaksanaan pembersihan. Pembersihan tidak hanya tentang memungut sampah sisa, melainkan juga mengembalikan barang sarana prasarana yang digunakan dalam ritual antara lain: ider-ider, tedung,umbul-umbul yang dikembalikan ke tempatnya semula.

\subsection{Aspek-aspek Dari Ritual Nyelung Sebagai Sumber Belajar Sejarah di SMA}

Aspek-aspek yang bisa dilihat dari pelaksanaan ritual Nyelung sebagai sumber pembelajaran sejarah dapat dipaparkan sebagai berikut:

\section{a) Sejarah (Sejarah Desa dan Ritual Nyelung)}

Sumber belajar sejarah itu bisa berbentuk peninggalan-peninggalan sejarah yang ada disekitar lingkungan sekolah atau tempat belajar. Salah satu yang dapat dijadikan sebagai sumber belajar adalah ritual Nyelung yang ada di desa Buahan dan Buahan Kaja.

Sebagai salah satusumber pembelajaran kita dapat menggunakan sejarah dari desa itu sendiri maupun sejarah dari ritual Nyelung. Materi tentang tradisi ini terdapat pada kurikulum 2013 pada mata pelajaran sejarah di SMA pada kelas X. Tradisi sebagai sumber belajar sejarah di SMA apabila diperhatikan pada kompetensi inti (KI) yaitu memahami, menerapkan, dan menganalisis pengetahuan faktual, konseptual, prosedural berdasarkan rasa ingin tahunya tentang ilmu pengetahuan, teknologi, seni, budaya, dan humaniora dengan wawasan kemanusiaan, kebangsaan, kenegaraan, dan peradaban terkait fenomena dan kejadian, serta menerapkan pengetahuan prosedural pada bidang kajian yang spesifik sesuai dengan bakat dan minatnya untuk memecahkan masalah. Sedangkan untuk Kompetensi Dasarnya (KD): menganalisis keterkaitan kehidupan awal manusia Indonesia dibidang kepercayaan, budaya, ekonomi dan teknologi serta pengaruhnya dalam kehidupan masa kini.

Ritual sebagai sumber pembelajaran nyata yang ada dalam kehidupan dapat meningkatkan daya tarik sehingga dapat memberikan rangsangan untuk belajar. Hal ini disebabkan karena materi pelajaran dikemas dalam bentuk lain dari biasanya yaitu dengan menggunakan identifikasi secara nyata, sehingga daya tarik peserta didik akan meningkat terhadap materi pelajaran.

\section{b) Pendidikan Karakter}

Ritual Nyelung yang dilaksanakan oleh kramasubak (warga pemilik sawah) setiap 10 tahun sekali merupakan warisan dari nenek moyang, yang keberadaanya sudah dari dahulu dan hingga sekarang masih tetap dilaksanakan tepatya di Pura Pucak Pausan, Desa Buahan Kaja.

Begitu pula terkait dengan makna dan tujuan pelaksanaan ritual Nyelung yang dilaksanakan pada Sasih Kasa (Kalender Bali) merupakan suatu wujud ungkapan rasa syukur terhadap Ida Sang Hyang widhi Wasa akan hasil panen khususnya hasil dari pertanian lahan sawah yang didapatkan oleh masyarakat yang menjadi petani. Sehubungan dengan 
itu, penting sekali untuk mengaitkan ritual Nyelung dengan pendidikan di sekolah khususnya sebagai pembelajaran sejarah di SMA kelas $\mathrm{X}$ jurusan IPS. Mengingat ritual Nyelung adalah salah satu kebudayaan yang diwariskan dari generasi ke generasi.

Mengenai aspek-aspek dari ritual Nyelung yang berpotensi sebagai sumber belajar sejarah di SMA. Akan diimplemntasikan melalui aspek nilai pendidikan karakter. Menurut Kementrian Pendidikan Nasional Indonesia menyatakan bahwa ada 18 nilai pendidikan karakter yang patut dikembangkan oleh setiap individu antara lain (1) Religius; (2) Jujur; (3) Toleransi; (4) Disiplin; (5) Kerja Keras; (6) Kreatif; (7) Mandiri; (8) Demokratis; (9) Rasa Ingin Tahu; (10) Semangat Kebangsaan; (11) Cinta Tanah Air; (12) Menghargai Prestasi; (13) Bersahabat; (14) Cinta Damai; (15) Gemar Membaca; (16) Peduli Lingkungan; (17) Peduli Sosial; (18) Tanggungjawab. Berdasarkan identifikasi peneliti, maka beberapa nilai yang tercermin dalam ritual Nyelung adalah sebagai berikut:

\section{Nilai Religius}

Nilai ini dapat diamati ketika mulai dari persiapan dimana setiap akan memulai pembuatan jelung terlebih dahulu akan dilaksanakan persembahyangan (banten canang) begitu pula tujuan inti dari ritual Nyelung sebagai wujud rasa syukur terhadap Tuhan Yang Maha Esa atas segala karuni yang telah diberikan melalui hasil panen, rasa syukur tersebut diimplementasikan dalam bentuk pembuatan banten serta persembahyangan bersama sebagai puncak acara di Pura Pucak Pausan

\section{Nilai Toleransi}

Sikap toleransi menjadi salah satu karakter yang penting untuk ditanamkan kepada peserta didik terutama untuk mengikis benih-benih perpecahan dan intoleransi yang sangat rentan mengancam negara Indonesia yang memiliki kondisi sosial yang sangat beragam. Pada saat inilah rasa tolrensi diperlukan untuk meredam ketegangan atau konflik karena perbedaan pendapat.

Nilai toleransi hanya dapat ditumbuhkan apabila peserta didik dibiasakan untuk memandang perbedaan bukan sebagai pemecah belah tetapi sebagai keragaman yang memperkaya budaya bangsa.

\section{Nilai Disiplin}

Telah dijelaskan pada bagian sebelumnya dimana masyarakat Desa Buahan dan Buahan Kaja mempunyai aturan atau awig-awig yang harus dipatuhi terkait hubungannya dengan ritual Nyelung. Dimulai dari peraturan menjaga tanah persawahan yang tidak boleh dipergunakan selain untuk pertanian.

Serta nilai kedisiplinan juga terlihat dari pelaksanaan ritual Nyelung yang tetap dilakukan 10 tahun sekali yang merupakan suatu kesepakatan dari nenek moyang mereka dan sampai dengan saat ini masih ditaati. Hal ini menunjukkan bahwa dalam kehidupan masyarakat sudah tertanan nilai disiplin yang sangat penting dalam setiap pelaksanaan ritual.

\section{Nilai Kerja Keras}

Nilai kerja keras juga dapat diamati pada saat pelaksanaan ritual, masyarakat bekerja keras dalam membawa hasil-hasil persembahan tersebut yang telah dijadikan satu dalam suatu tempat, adapun membawanya secara bergantian dari 
masing-masing banjar. Peserta didik dapat mencontoh hal tersebut mengingat bahwa kerja keras adalah suatu proses menuju keberhasilan dalam melaksanakan suatu kegiatan.

\section{Nilai Persahabatan}

Melalui pelaksanaan ritual khususnya ritual Nyelung yang tidak hanya dilaksanakan 1 (satu) banjar melainkan dilaksanakan oleh 2 Desa (13 banjar) interaksi antar individu atau kelompok tersebut akan tercipta rasa persahabatan dan komunikasi sehingga mempererat rasa kebersamaan masyarakat. Persahabatan juga dapat tercipta antar sesama petani yang bisa saling mengenal satu sama lain walaupun berasal dari banjar yang berbeda-beda.

\section{Nilai Cinta Damai}

Dalam ritual Nyelung ini banyak orang berkumpul dalam satu tempat yang sama. Mereka berasal dari banjar yang berbeda namun tetap pada tujuan yang sama, ialah untuk menyukseskan pelaksanaan ritual Nyelung. Mustahil orang-orang ini mau berkumpul jika kehadiran mereka akan menimbulkan rasa tidak senang dan tidak aman atau malah mereka sendiri merasa tidak senang dan tidak aman untuk berada di tempat tersebut.

\section{Nilai Peduli Lingkungan}

Implementasi dari rasa peduli lingkungan dalam pelaksanaan ritual Nyelung dapat dilihat pada masing-masing krama subak yang melakukan persembahyangan di masing-masing tugu (pura kecil) dan memercikan tirta (air suci) telah didapat dalam pelaksanaan ritual Nyelung. Sebagai bentuk permohonan keselamatan terhadap pertanian mereka serta menjaga tanah sawah mereka agar tetap menjadi lahan pertanian melalui aturan yang dibuat krama subak.

\section{Nilai Peduli Sosial}

Sebagaimana yang telah dijelaskan bahwa para petani tergabung dalam sebuah kelompok yang disebut subakmemilki ikatan sosial yang tinggi. Salah satu contoh misalnya ketika masyarakat yang tergabung dalam krama subak membantu memperbaiki saluran irigasi yang mengairi perawahan mereka demi kelancaran hasil pertanian mereka.

\section{Nilai Tanggung Jawab}

Nilai-nilai tanggung jawab dapat diamati ketika setiap komponen yang berperan dalam penyelenggaraan ritual Nyelung ini melakukan setiap tugas dan tanggung jawabnya masing-masing. Sebuah kegiatan hanya dapat berjalan lancar ketika setiap komponen pendukung kegiatan tersebut dapat menyadari tanggungjawabnya masing-masing serta melaksanakannya dengan baik.

\section{Nilai Kreatif}

kreatif dalam pelaksanaan ritual Nyelung dapat diamati pada bagian luar kotak yang digunakan untuk menampung hasil-hasil pertanian warga yang dipersembahkan, dimana kotak tersebut dihiasi sedemikian indah dengan tempelan kertas yang telah di ukir dan di setiap sudutnya dihiasi tedung (payung Bali yang lazim dipasang di Pura) berwarna putihkuning. 


\subsection{Pengintegrasian Aspek-aspek Ritual Nyelung Dalam Pembelajaran Sejarah Berbentuk Buku Suplemen}

\section{a) Rancangan Buku Suplemen}

Salah satu usaha untuk membuat ritual Nyelung tetap dikenal sehingga makin banyak pihak yang peduli untuk melestarikannya adalah melalui sosialisasi salah satunya adalah melalui pendidikan formal khususnya pada tingkat SMA melalui mata pelajaran sejarah.

Materi yang dikembangkan dalam pembelajaran hendaknya mengedepankan keunggulan dan kebutuhan daerah, berupa keunggulan lokasi, ekonomi, sosial, politik, sejarah dan budaya (Kementerian Pendidikan dan Kebudayaan, 2016). Hasil penelitian tentang ritual Nyelung ini dimanfaatkan sebagai rancangan buku suplemen sumber belajar sejarah di SMA kelas X.

\section{PENUTUP}

\section{A. KESIMPULAN}

Berdasarkan paparan di atas dapat disimpulkan bahwa, latar belakang pelaksanaan Ritual Nyelung di Desa Buahan dan Buahan Kaja, Payangan, Gianyar, Bali ada enam, yang pertama ialah latar belakang historis pelaksanaan ritual Nyelung yang telah dilaksanakan secara turun-temurun.

Selain latar belakang historis terdapat pula hal lainnya antara lain (1) kekhawatiran akan hal-hal gaib, (2) media memohon kesubura, (3) memperkuat Tri Hita Karana, (4) pemertahanan kesenian dan tradisi banten, (5) ritual Nyelung sebagai destinasi pariwisata. Ritual Nyelung adalah bentuk wujud syukur dari masyarakat Buahan dan Buahan Kaja, terhadap Tuhan Yang Maha Esa atas hasil panen yang mereka dapatkan dari hasil pertanian sawah.. Saat prosesi pelaksanaan ritual Nyelung ini, dilakukan pada sasih kasa. Setiap pelaksanaanya diawali dari tahap persiapan, yaitu penentuan tanggal kegiatan yang dilakukan dengan cara musyawarah dengan semua elemen masyarakat, selanjutnya tahap pelaksanaan ritual yang terdiri dari acara (Negen) membawa jelung ketempat tujuan, upacara mekideh dengan mengelilingi areal pura sebanyak 3 kali putaran dan mekeleb atau menghaturkan persembahan ke areal utama pura (Jeruan). Tahap terakhir ialah penutupan ritual yang berisi persembahyangan bersama dan nunas tirta, serta pembersihan di arela Pura Pucak Pausan.

Dalam ritual Nyelung, terdapat beberapa aspek-aspek yang penting untuk dijadikan sebagai sumber belajar sejarah di SMA kelas X khususnya. Aspek-aspek yang dimaksud ialah, (1) aspek sejarah, dalam hal ini sejarah yang dimaksud ialah sejarah desa dan sejarah lahirnya ritual Nyelung, (2) aspek pendidikan karakter, adapun pendidikan karakter yang terdapat dalam ritual Nyelung antara lain: (a) religius, (b) toleransi, (c) disiplin, (d) kerja keras, (e) persahabatan, (f) cinta damai, (g) peduli lingkungan, (h) peduli sosial, (i) tanggungjawab, (j) kreatif.

\section{B. SARAN}

Sebagai akhir dari tulisan, ini penulis memberikan saran dan masukan dalam kapasitas sebagai masyarakat maupun sebagai seorang peneliti. Adapun saran yang dapat diberikan yaitu :

\section{Guru}

Guru diharapkan dapat menjadikan ritual Nyelung untuk dimasukan dalam materi pembelajaran khususnya sejarah. 


\section{Peserta Didik}

Ritual Nyelung diharapkan dapat dipergunakan sebagai sumber belajar di luar sekolah, sehingga pemahaman dan hasil belajar siswa khususnya yang berkaitan dengan sejarah kebudayaan meningkat.

\section{Masyarakat}

Masyarakat diharapkan ikut serta dalam memberikan pengetahuan lebih dalam terhadap generasi penerunya.

\section{Pemerintah}

Pemerintah dapat secara berkelanjutan mempublikasikan ritual Nyelung, sebagai salah satu kebudayaan yang menjadi ciri khas suatu daerah, khususnya daerah Gianyar.

\section{DAFTAR PUSTAKA}

Atmadja. 2016. Bali Pulau Banten Perspektif Sosiologi Komodifikasi Agama. Singaraja: Pustaka Larasan.

Ngurah, dkk. 1999. Pendidikan Agama Hindu Untuk Perguruan Tinggi. Surabaya: PARAMITHA.

Wiana, K. 2002. Memelihara Tradisi Weda. Denpasar: BP. 